\title{
Impact of Aerobic Stabilization of Sewage Sludge on PAHs Concentration in Reject Waters
}

\author{
Jolanta Kozak', Maria Włodarczyk-Makuła', Agnieszka Popenda ${ }^{1 *}$ \\ 1 Faculty of Infrastructure and Environment, Czestochowa University of Technology, \\ Dabrowskiego 69, 42-200 Czestochowa, Poland \\ * Corresponding author's email: apopenda@is.pcz.czest.pl
}

\begin{abstract}
In the paper, the results of studies on changes in the concentration of selected polycyclic aromatic hydrocarbons (PAHs) in the reject water coming from aerobic stabilization of sewage sludge process were given. The sewage sludge samples originating from a treatment of municipal wastewater treatment plant and an industrial coking wastewater treatment plant were investigated. A technological study was conducted using a municipal sewage sludge (control sample) and a mixture of municipal and industrial sewage sludge simultaneously. Aerobic stabilization of sewage sludge process was carried out for 21 days. The concentration of PAHs was determined at the beginning of the experiment (day 0 ) and in seven-day intervals: after 7, 14 and 21 days. The initial concentration of PAHs in the reject water coming from the municipal sewage sludge was over $44 \mathrm{~g} / \mathrm{dm}^{3}$. Industrial sewage sludge was heavily loaded with polycyclic aromatic hydrocarbons. In a reject water of the mixture of municipal and industrial sludge, the initial content of PAHs reached over $5200 \mathrm{~g} / \mathrm{dm}^{3}$. During aerobic stabilization of sewage sludge, a decrease in PAHs concentration in reject water was observed. After 21 days of the experiment, the decrease of the sum of analyzed PAHs was in the range of $62-98 \%$.
\end{abstract}

Keywords: PAHs, municipal sewage sludge, coking sewage sludge, reject water, aerobic stabilization

\section{INTRODUCTION}

Sewage sludge, as by-product of the wastewater treatment process, is formed during series of stages of the wastewater treatment. The physicalchemical composition of sewage sludge is diversified and depends on the type of sewage and the applied methods of treatment (Kelessidis et al., 2012). The construction of new and modernization of the existing wastewater treatment plants as well as the application of highly effective treatment methods results in the increase of the amount of sewage sludge (Statistical yearbook, 2020). Municipal and industrial sewage sludge can be distinguished depending on the type of treated wastewater. According to the current regulations, it is necessary to treat sewage sludge in order to achieve well-decomposed organic compounds. Therefore, methane fermentation or aerobic stabilization of sewage sludge process can usually be applied. However, it should be noted that not only easily biodegradable pollutants are present in sewage sludge. Municipal and industrial sewage sludge contains both organic and inorganic compounds classified as hardly degradable pollutants as well as toxic contaminants. Heavy metals are listed among inorganic compounds, whereas, polycyclic aromatic hydrocarbons (PAHs), polychlorinated biphenyls (PCBs), active halogens adsorbed on activated carbon, expressed by the AOX index, organic halogen or polychlorinated dibenzodioxins or dibenzofurans (PCDD/PCDF) should be mentioned among organic ones (Fijałkowski et al., 2017, Haddaoui et al., 2016, Qu et 1., 2019, Petersen et al., 2003). Polycyclic aromatic hydrocarbons belong to the group of persistent organic pollutants (POPs) and their presence in sewage sludge has been confirmed both in literature sources and former studies of co-authors (Fijałkowski et al., 2017, 
Haddaoui et al., 2016, Qu et al., 2019, Petersen et al., 2003, Zennegg et al., 2013, Liu et al., 2013, Wlodarczyk-Makuła et al., 2015). It should be highlighted that in most studies the PAHs content in reject water is omitted; thus, the previous co-authors' research considered the presence of polyaromatic hydrocarbons in reject water. This problem is of high importance because the reject water coming from sewage sludge treatment is disposed together with raw wastewater into the technological wastewater treatment process. A significant amount of PAHs in wastewater can be found in sewage sludge due to their physical and chemical properties as well as due to the easy adsorption by solids (Dat et al., 2017). The characteristic of selected PAHs is included in Table 1.

Although the water solubility of PAHs is low, they can also be found in reject water, oils film and fats surrounding sludge particles (Fijałkowski et al., 2017). These compounds are highly toxic to organisms. Depending on the number of aromatic rings in molecule, PAHs can be classified as light and heavy. The hydrocarbons of 2 to 3 rings are classified as light, and volatile due to high vapor pressure. The hydrocarbons containing 4 and more rings in molecule are identified as heavy ones (Rubio-Clemente et al., 2014, Kozak et al., 2018, Abdel-Shafy et al., 2016, Lawal, 2017).

In aerobic stabilization of sewage sludge process, the supplied oxygen is consumed by microorganisms to oxidize organic compounds. The presence of oxygen results in sufficient mixing of sewage sludge and counteracts the process of putrefaction. Generally, PAHs are resistant to degradation due to their low bioavailability. It is known that under aerobic conditions, PAHs are biodegraded by various strains of bacteria, algae or fungi, which use different types of oxygenases, including: monooxygenase, cytochromedependent oxygenase and dioxygenase (Liu et al., 2017, Gupte et al., 2016, Abbasian et al., 2015). Among others, Rhodococcus, Acinetobacter, Mycobacterium spp., Haemophilus spp., Rhodococcus spp., Paenibacillus spp. and Pseudomonas are involved in the process and use PAHs as a sole source of carbon and energy. Due to the presence of oxygen and bacteria, the organic compounds are biodegradable, forming final simple inorganic products. It should be pointed out that the biodegradation process can lead to the production of toxic by-products difficult to identify. Taking into considerations biodegradation of PAH the process is more efficient for light hydrocarbons than for higher molecular weight compounds (Haritash et al., 2009).

The concentrations of PAH in sewage sludge may limit its application e.g. in agriculture. Furthermore, high concentrations of PAH in reject water may negatively affect raw wastewater with an additional amount of these toxic compounds.

Directive of EU 1986/278/ EEC (Council Directive 86/278/EEC, 1986), proposes the permissible content of 11 PAHs (acenaphthene, fenanthrene, fluorene, fluoranthene, pyrene, benzo(b) fluoranthene, benzo(j)fluoranthene, benzo(k) fluoranthene, benzo(a)pyrene, benzo(g,h,i)perylene, indeno(1,2,3-c,d)pyrene) at $6 \mathrm{mg} / \mathrm{kg}$ dry mass of sewage sludge. Therefore, the sewage sludge treatment processes enabling to efficiently remove PAHs are of increasing importance. The literature sources state that the PAHs decrease under aerobic conditions is higher than that under anaerobic conditions and that biodegradation occurs to a greater degree under aerobic conditions. Other studies prove that sorption is the dominant process in PAHs degradation in biochemical processes. However, the experiments were carried out using individual hydrocarbons or their mixtures added to the water or soil samples in known amount. The studies on PAHs removal from industrial sewage sludge under aerobic conditions are also very limited. Therefore, the aim of the studies was to analyze the changes in the concentration of selected aromatic hydrocarbons in the aerobic stabilization of sewage sludge process.

\section{METHODOLOGY}

\section{Materials}

The experiment was carried out using two types of sewage sludge: excessive sewage sludge originating from a municipal treatment plant (S11) and the sewage sludge coming from an industrial treatment plant (S12).

Municipal sewage sludge was sampled from recirculation from a secondary settling tanks of a municipal treatment plant of 100000 PE (equivalent population). In the technological process, denitrification and nitrification along with the oxidation of organic pollutants are carried out in the activated sludge chambers. Industrial sewage sludge (S12) was taken from the reservoir of excessive sludge. The wastewater in this treatment plant is destined for biological treatment (denitrification, carbon oxidation, and nitrification). 


\section{Experimental}

Aerobic stabilization was carried out in two open reactors (volume of each reactor was equal to $14 \mathrm{dm} 3$ ) with continuous air supply $(\mathrm{Q}=60 \mathrm{dm} 3 / \mathrm{h})$ to maintain the excess of the oxygen in the reactors. The aquarium stone diffusers made of quartzite sand were placed in the bottom of both reactors. The process was carried out under laboratory conditions, at ambient temperature that varied in the range of $18-22{ }^{\circ} \mathrm{C}$ (average temperature was equal to $20^{\circ} \mathrm{C}$ ) (Fig. 1). Municipal sewage sludge (S11) was treated as a control sample, whereas another reactor was filled with a mixture of municipal sewage sludge and industrial sewage sludge $(\mathrm{S} 12)(3: 1 \mathrm{v} / \mathrm{v})$. Both municipal sewage sludge as well as a mixture of municipal sewage sludge and industrial sewage sludge were continuously aerated over 21 days. The time of aeration and volume of sewage sludge were chosen based on literature data (Macherzyński et al., 2018). The samples of reject water to be analyzed for PAHs content were taken at the beginning of experiment (day 0), and then in seven-day intervals: after 7,14 and 21 days of conducting the experiment.

\section{PAHs analysis}

The PAHs concentration in reject water sample was determined after centrifuging the freshly taken sewage sludge (15000 rpm over $10 \mathrm{~min}$ ). Extraction of organic compounds was carried out using the liquid-liquid method by adding the mixture of cyclohexane and dichloromethane $(5 / 1 \mathrm{v} / \mathrm{v})$ to the reject water. The samples were shaken using a laboratory shaker for 60 minutes. Afterwards, the separated extracts were dried using anhydrous aluminum sulfate and purified under vacuum on silica gel. Then, the purified extract was concentrated under a stream of nitrogen to a volume of $2 \mathrm{~cm}^{3}$. Finally, qualitative and quantitative analysis of PAHs using GC-MS system was conducted. Helium was used (flow rate of $1.08 \mathrm{~cm}^{3} / \mathrm{min}$ ) as a carrier gas. Subsequently, $2 \mathrm{~mm}^{3}$ of the concentrated sample was injected into DB-5 column (length $30 \mathrm{~m}$, diameter $0.25 \mathrm{~mm}$, thickness $0.25 \mu \mathrm{m})$. MS 800 spectrometer was used for the detection and identification step, containing an EI type ion source with the ionization energy of $70 \mathrm{eV}$. Selective ion monitoring (SIM) $\mathrm{m} / \mathrm{z}$ was applied. Three representative ions were chosen for each PAH. The temperature program was as follows: $40^{\circ} \mathrm{C} / \mathrm{min}$, heating 5 to $120^{\circ} \mathrm{C}$, and the final temperature was $280^{\circ} \mathrm{C}$ for 60 minutes. The following PAHs listed by US EPA were determined: naphthalene, acenaphthylene, acenaphthene, fluorene, phenanthrene, anthracene, fluoranthene, pyrene, benzo(a)anthracene and chrysene. The selected PAH parameters are included in Table 1.

\section{RESULTS}

The total concentration of PAHs in reject water of the control chamber (S11) containing the sewage sludge from the municipal wastewater treatment plant was equal to $46 \mu \mathrm{g} / \mathrm{dm} 3$ at the beginning of the experiment (day 0). The PAHs content in reject water from the mixture of municipal sewage sludge and industrial sewage sludge (S12) $(3: 1 \mathrm{v} / \mathrm{v})$ was much higher and equal to $5387 \mu \mathrm{g} / \mathrm{dm}^{3}$ at the same time. Figure 2 shows the changes in the concentration of naphthalene in reject water during aerobic sewage sludge

Table 1. Characteristic of selected PAHs (Dat et al., 2017, Rubio-Clemente et al., 2014)

\begin{tabular}{|c|c|c|c|c|c|c|c|c|}
\hline No. & $\mathrm{PAHs}$ & Symbol & $\begin{array}{l}\text { Number } \\
\text { of rings }\end{array}$ & Formula & Recovery [\%] & $\begin{array}{l}\text { Limit of } \\
\text { detection } \\
{\left[\mu \mathrm{g} / \mathrm{dm}^{3}\right]}\end{array}$ & $\log \mathrm{K}_{0 \mathrm{w}}$ & $\begin{array}{c}\text { Solubility } \\
\text { in water in } 25^{\circ} \mathrm{C} \\
{\left[\mu \mathrm{g} / \mathrm{dm}^{3}\right]}\end{array}$ \\
\hline 1 & Naphthalene & NAP & 2 & $\mathrm{C}_{10} \mathrm{H}$ & 102.2 & 11.1 & 3.37 & 31700 \\
\hline 2 & Acenaphthylene & $A C Y$ & \multirow{5}{*}{3} & $\mathrm{C}_{16} \mathrm{H}_{10}$ & 51.5 & 20.1 & 4.07 & 3930 \\
\hline 3 & Acenaphthene & ACP & & $\mathrm{C}_{12} \mathrm{H}_{10}$ & 91.3 & 9.9 & 4.33 & 3900 \\
\hline 4 & Fluorene & FLT & & $\mathrm{C}_{13} \mathrm{H}_{10}$ & 83.2 & 0.2 & 4.18 & 1980 \\
\hline 5 & Phenanthrene & FHE & & $\mathrm{C}_{14} \mathrm{H}_{10}$ & 85.3 & 0.2 & 4.57 & 1290 \\
\hline 6 & Anthracene & ANT & & $\mathrm{C}_{14} \mathrm{H}_{10}$ & 76.1 & 0.1 & 4.54 & 73 \\
\hline 7 & Fluoranthene & FLR & \multirow{4}{*}{4} & $\mathrm{C}_{16} \mathrm{H}_{10}$ & 98.1 & 0.1 & 5,16 & 265 \\
\hline 8 & Pyrene & PYR & & $\mathrm{C}_{16} \mathrm{H}_{10}$ & 102.9 & 0.1 & 5.32 & 135 \\
\hline 9 & Benzo(a)anthracene & $\mathrm{BaA}$ & & $\mathrm{C}_{18} \mathrm{H}_{12}$ & 65 & 0.1 & 5.61 & 14 \\
\hline 10 & Chrysene & $\mathrm{CHR}$ & & $\mathrm{C}_{18} \mathrm{H}_{12}$ & 65 & 0.1 & 5.63 & 2.0 \\
\hline
\end{tabular}




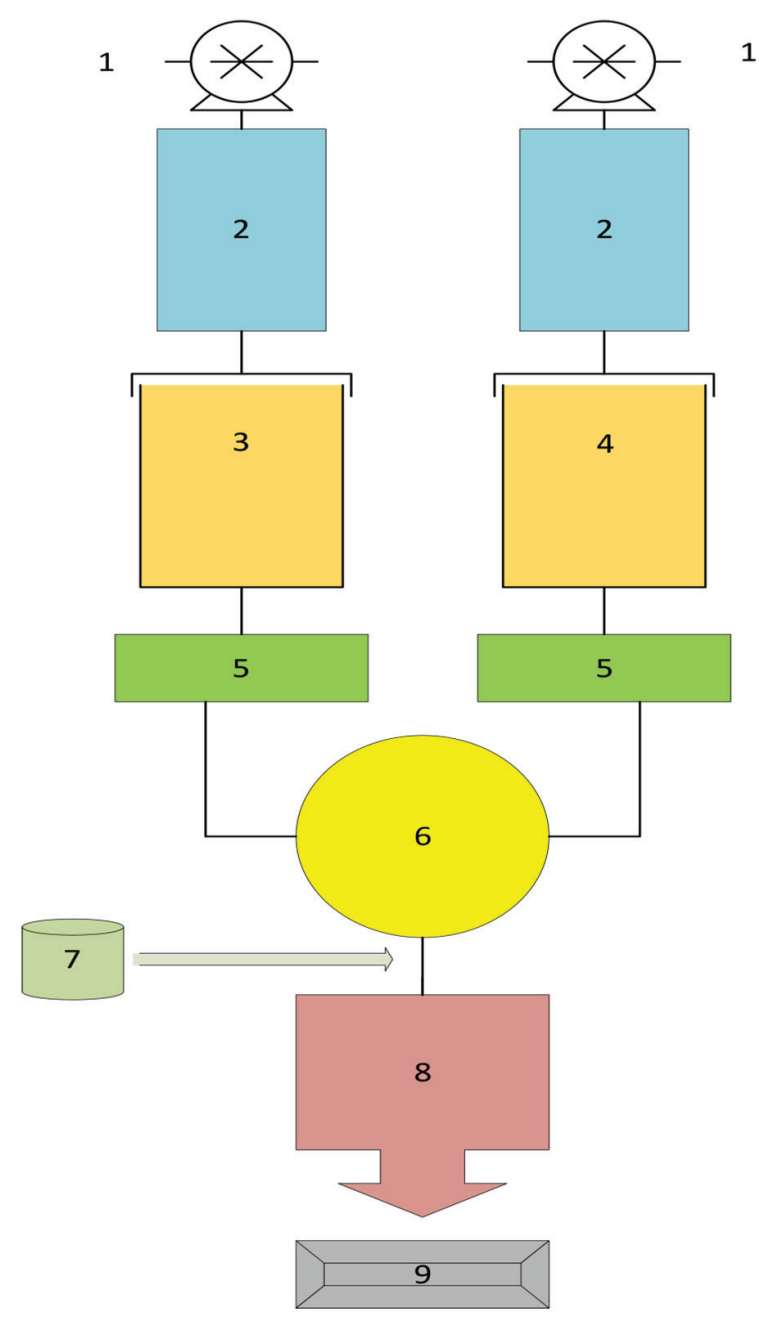

Fig. 1. Research scheme: 1 - pump, 2 - flowmeter, 3 reactor SI1, 4 - reactor SI2, 5- samples, 6-centrifuge, 7 - organic solvents, 8 - PAHs extraction, 9 - GC-MS

stabilization process. The initial concentration of naphthalene (day 0) in reject water (S11) was equal to $1.85 \mu \mathrm{g} / \mathrm{dm}^{3}$, whereas in the sample (S12) was equal to $95.2 \mu \mathrm{g} / \mathrm{dm}^{3}$, respectively. The highest decrease in the concentration of naphthalene in reject water (S11) was observed after 21 days of carrying the experiment, whereas in (S12) after 14 days of the process. The percentage loss of the studied hydrocarbon was $32 \%\left(1.25 \mu \mathrm{g} / \mathrm{dm}^{3}\right)$ and over $99 \%\left(0.43 \mu \mathrm{g} / \mathrm{dm}^{3}\right)$, respectively.

Figure 2 shows the changes in the concentration of naphthalene and 3-ring hydrocarbons during the aerobic sewage sludge stabilization process. Phenanthrene was the most dominant 3-ring hydrocarbon in the sample containing the sewage sludge from the municipal wastewater treatment (S11) with the initial concentration of $12.53 \mu \mathrm{g} / \mathrm{dm}^{3}$, whereas acenaphthene occurred in the highest amount in reject water of sewage sludge (S12) with the initial concentration of $2276.52 \mu \mathrm{g} / \mathrm{dm}^{3}$ (Fig. 3).

The initial concentration of acenaphthylene (day 0 ) in the reject water from sewage sludge coming from the municipal wastewater treatment (S11) - was equal to $0.19 \mu \mathrm{g} / \mathrm{dm}^{3}$ (Fig. 2), whereas in the reject water of sewage sludge (S12) - it was equal to $67.6 \mu \mathrm{g} / \mathrm{dm}^{3}$ (Fig. 3). At the end of aerobic sewage sludge stabilization process (after 21 days) a decrease in the concentration of acenaphthylene in the reject water coming from both control sewage sludge (S11) and (S12) was observed. The percentage loss of the afore mentioned hydrocarbon was: $36 \%\left(0.12 \mu \mathrm{g} / \mathrm{dm}^{3}\right)$ and $99.8 \%\left(0.11 \mu \mathrm{g} / \mathrm{dm}^{3}\right)$ after 21 days of aerobic sewage sludge stabilization process, respectively.

Among 3-ring hydrocarbons acenaphthene was also determined during the aerobic sewage sludge stabilization experiment (Fig. 2 and 3). The initial concentration of acenaphthene (day 0 ) in the reject water coming from the municipal sewage sludge (S11) was equal to $7.12 \mu \mathrm{g} / \mathrm{dm}^{3}$, whereas in the reject water of sewage sludge (S12), it reached the value of $2276.5 \mu \mathrm{g} / \mathrm{dm}^{3}$. After 7 days of conducting aerobic sewage sludge stabilization process, almost a six-fold increase in the concentration of acenaphthene was observed, while after 14 days of carrying process, a large drop of concentration in the reject water from sewage sludge (S11) appeared. Extending the stabilization time to 21 days did not improve the effect of decomposition significantly. In the reject water originating from sewage sludge (S12) a decrease in acenaphthene concentration was noticed. The percentage loss of the studied hydrocarbon in the reject water of the sewage sludge (S11) was $66 \% 2.4 \mu \mathrm{g} / \mathrm{dm}^{3}$ and $99.9 \%$ in the sewage sludge (S12) $2.7 \mu \mathrm{g} / \mathrm{dm}^{3}$, respectively.

The initial concentration of fluorene (day 0 ) in the reject water originating from the municipal sewage sludge (S11) was equal to $7.34 \mu \mathrm{g} / \mathrm{dm}^{3}$, whereas in the reject water coming from the sewage sludge (S12) it amounted to $1364.76 \mu \mathrm{g} / \mathrm{dm}^{3}$ (Fig. 2 and Fig. 3). The highest decrease in concentration of fluorene in the reject water from the municipal sewage sludge (S11) was noted after 21 days of the stabilization process $\left(1.96 \mu \mathrm{g} / \mathrm{dm}^{3}\right)$. The most efficient aeration time for the reject water from the sewage sludge (S12) was 14 days and allowed reducing the concentration of fluorene of $99.2 \%$ to the value of $9.68 \mu \mathrm{g} / \mathrm{dm}^{3}$.

The initial concentration of phenanthrene (day 0 ) in the reject water from the municipal 


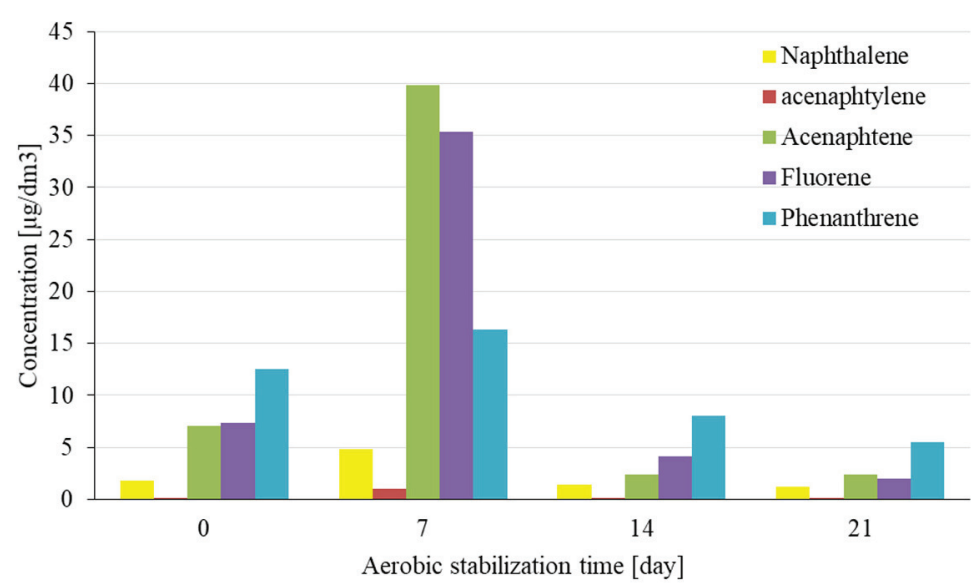

Fig. 2. Concentration of naphthalene and 3-ring PAHs during aerobic sewage sludge stabilization (reactor S11)

sewage sludge (S11) was $12.54 \mu \mathrm{g} / \mathrm{dm}^{3}$, whereas in the reject water from the sewage sludge (S12) ranged the value of $1447.12 \mu \mathrm{g} / \mathrm{dm}^{3}$, respectively (Fig. 2 and Fig. 3). After 21 days of conducting the aerobic sewage sludge stabilization experiment, the highest decrease in the concentration of phenanthrene in the reject water from the municipal sewage sludge (S11) occurred, while after 7 days of aerobic sewage sludge stabilization a slight increase in the concentration of the studied hydrocarbon was noticed. In the reject water of the sewage sludge (S12) the highest decrease in the concentration was noticed after 14 days of the experiment, while extension of the aerobic sewage sludge stabilization process resulted in a slight increase in the phenanthrene concentration. The percentage reduction of the investigated hydrocarbon was $55.7 \%\left(5.55 \mu \mathrm{g} / \mathrm{dm}^{3}\right)$ and $99.8 \%\left(2.26 \mu \mathrm{g} / \mathrm{dm}^{3}\right)$, respectively. Among 3 -ring PAHs, anthracene was also considered, but the determined concentrations of this hydrocarbon were below the detection limit in all the samples taken from the sewage sludge during the whole experiment.
Summarizing the changes in the concentration of 3-ring PAHs, the fluctuating concentrations of individual hydrocarbons in the reject water were observed. Taking into considerations the sum of 3 -ring PAHs in the reject water originating from the municipal sewage sludge after 7 days of the experiment, it should be noted that an increase in concentration compared to the initial one was observed. It is probably due to the process of formation the afore mentioned products from more complex compounds. During the experiment, a gradual decrease in the concentration of sum of 3-ring PAHs in the reject water was observed. In the reject water coming from the sewage sludge (S11), the highest decrease of 3-ring PAHs appeared after 14 days of the aerobic sewage sludge stabilization process. The extension of the process did not result in significant changes in PAH concentrations. After 21 days of the aerobic sewage sludge stabilization process in the reject water from the municipal sewage sludge (S11), the decrease in PAHs concentration was $60 \%$ on average, whereas in the reject water of the sewage sludge (S12), decrease reached $99 \%$ after 14 days of the experiment,

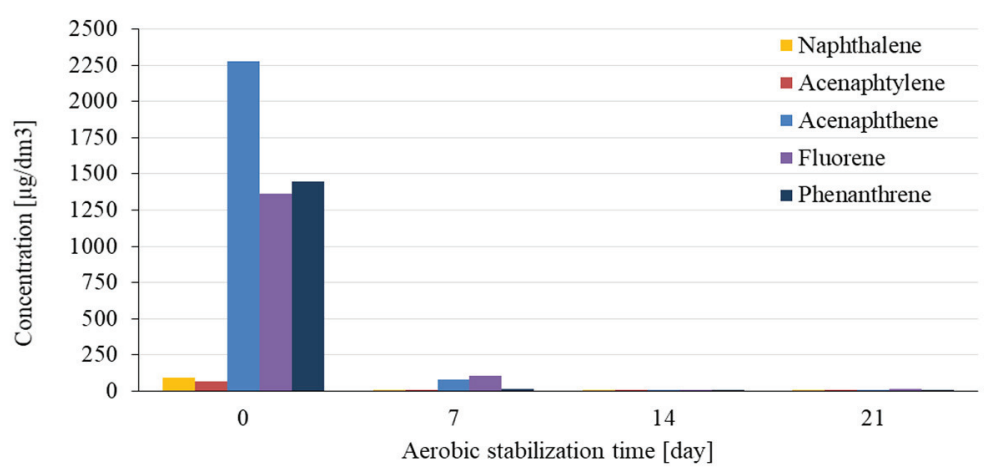

Fig. 3. Concentration of naphthalene and 3-ring PAHs during aerobic sewage sludge stabilization (reactor S12) 
respectively. The total PAHs concentration in the reject water from the municipal sewage sludge (S11) was $10.08 \mu \mathrm{g} / \mathrm{dm}^{3}$ after 21 days, whereas in the reject water coming from the sewage sludge (S12) $19.74 \mu \mathrm{g} / \mathrm{dm}^{3}$, respectively.

In Figures 4 and 5, changes in the concentration of 4-ring hydrocarbons during aerobic sewage sludge stabilization process is shown. The sum of 4-ring hydrocarbons in the reject water from municipal sludge (S11) was $17.1 \mu \mathrm{g} / \mathrm{dm}^{3}$, whereas in the sewage sludge (S12) ranged the value of $136.44 \mu \mathrm{g} / \mathrm{dm}^{3}$, respectively. Fluoranthene was the dominant hydrocarbon in the reject water both in the sewage sludge (S11) $\left(6.26 \mu \mathrm{g} / \mathrm{dm}^{3}\right)$ and in the sewage sludge (S12), $\left(72.44 \mu \mathrm{g} / \mathrm{dm}^{3}\right)$, respectively. Irregular changes in the fluoranthene concentration in the reject water coming from both municipal sewage sludge and mixed sewage sludge was observed during the aerobic sewage sludge stabilization process.

After 21 days of the experiment, the highest decrease in the fluoranthene concentration in the reject water from the municipal sewage sludge was observed. The highest decrease in the fluoranthene concentration was noted in the reject water originating from (S12) after 14 days of aerobic stabilization (Fig. 5). These changes were $54.5 \%\left(2.85 \mu \mathrm{g} / \mathrm{dm}^{3}\right)$ and $78.2 \%\left(15.82 \mu \mathrm{g} / \mathrm{dm}^{3}\right)$ respectively

Pyrene was another studied hydrocarbon. The initial concentration of this compound in the reject water from the municipal sewage sludge (S11) was equal to $4.29 \mu \mathrm{g} / \mathrm{dm}^{3}$, whereas in the reject water from the sewage sludge (S12) it reached the value of $43.03 \mu \mathrm{g} / \mathrm{dm}^{3}$, respectively (Fig. 4 and Fig. 5). In the reject water originating from the sewage sludge (S12) the most significant decrease was found after 14 days of the process; however, the increase in concentration of this compound was noticed after 21 days. The highest decrease in the concentration of pyrene was $63.4 \%$ (S11) $1.57 \mu \mathrm{g} / \mathrm{dm}^{3}$ and $77.4 \%$ (S12) $9.69 \mu \mathrm{g} / \mathrm{dm}^{3}$, respectively.

Considering benzo(a)anthracene, the initial concentration in reject water from the municipal sewage sludge (S11) was $2.34 \mu \mathrm{g} / \mathrm{dm}^{3}$, whereas in the supernatant from the sewage sludge (S12) it was equal to $8.9 \mu \mathrm{g} / \mathrm{dm}^{3}$ (Fig. 4 and Fig. 5, respectively). The highest decrease of benzo(a)anthracene concentration in the reject water from the municipal sewage sludge occurred at the end of the experiment (after 21 days), whereas a slight increase in the concentration of the afore mentioned hydrocarbon was noticed after 7 days of aerobic sewage sludge stabilization process. In the reject water from the sewage sludge (S11) the highest decrease in concentration occurred after 14 days of the stabilization, and at the end of the process a higher concentration was noticed. The highest decrease in the benzo(a)anthracene concentration was: $73.5 \%\left(0.6 \mu \mathrm{g} / \mathrm{dm}^{3}\right)$ and $44.8 \%$ $\left(4.91 \mu \mathrm{g} / \mathrm{dm}^{3}\right)$, respectively.

Considering the concentration of chrysene in the reject water coming from the municipal sewage sludge (S11) it decreased by $79.6 \%$ reaching the value of $0.86 \mu \mathrm{g} / \mathrm{dm}^{3}$ compared to the initial value of $4.22 \mu \mathrm{g} / \mathrm{dm}^{3}$ after 21 days of the experiment. In the reject water coming from the mixture of municipal sewage sludge and industrial sewage sludge (S12), the highest decrease in the chrysene concentration was noted after 14 days of the aerobic sewage sludge stabilization process. The percentage loss was $62 \%$, with the concentration dropping from $12.06 \mu \mathrm{g} / \mathrm{dm}^{3}$ to $4.58 \mu \mathrm{g} / \mathrm{dm}^{3}$ (Fig. 4 and Fig. 5).

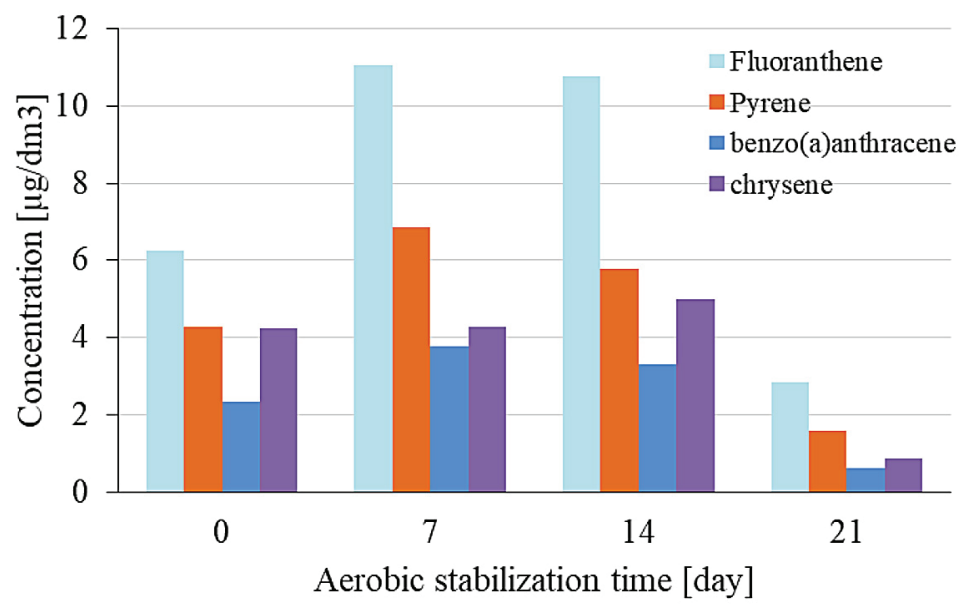

Fig. 4. Concentration of 4-ring PAHs during aerobic sewage sludge stabilization (reactor S11) 
Taking into considerations the total concentration of 4-ring PAHs, it can be noticed that in the reject water originating from the municipal sewage sludge (S11) an increase in concentration compared to the initial concentration was observed after 7 days of the process. This observation is analogous to the results describe above with respect to 3-ring hydrocarbons. A gradual decrease in the concentration of the afore mentioned compounds was found after 14 days of aerobic sewage sludge stabilization process. The highest efficiency of PAHs reduction took place in the reject water from the sewage sludge (S12) after 14 days of the process, whereas higher concentrations of studied PAHs were observed after 21 days. The total concentration of analyzed PAHs was equal to $5.89 \mu \mathrm{g} / \mathrm{dm}^{3}$ in the sample of sewage sludge (S11) after 21 days of the experiment and the reduction of $65.4 \%$ was achieved. The highest reduction of PAHs equal to $74.34 \%\left(35.01 \mu \mathrm{g} / \mathrm{dm}^{3}\right)$ occurred in the sewage sludge (S12) after 14 days of the aerobic sewage sludge stabilization process.

Considering the changes in PAHs concentration in the reject water separated from the sewage sludge (S12) containing 2 and 3 aromatic rings in molecules, it can be concluded that a decrease in the content was higher than those in 4-ring hydrocarbons. Naphthalene and 3-ring hydrocarbons are characterized by high volatility; therefore, the larger decrease in the concentration result most probably due to their volatilization during the aerobic sewage sludge stabilization process. The decrease of hydrocarbon removal from the reject water of the sewage sludge (S12) was higher than that from the sewage sludge (S11) which indicates that the microorganisms present in the coke sewage sludge are able to degrade PAHs. Most likely, this ability may result from the fact that they are adapted to the presence of these compounds in the wastewater treated in the coking plant.

It should be highlighted that the comparison of the obtained results with the data available in the literary sources is difficult due to various research methodologies, applied experimental conditions as well as characteristics of the investigated material. In addition, the data on the effectiveness of $\mathrm{PAH}$ removal from the municipal and industrial sewage sludge under the aerobic sewage sludge stabilization process is insufficient. The available results focus on using individual hydrocarbons or PAHs mixture with the known concentration added to the water or to the soil samples. Under the technological conditions, sewage sludge contains various pollutants affecting the efficiency of the process. The aerobic sewage sludge stabilization process is usually used for a small amount of sewage sludge (up to $10000 \mathrm{PE}$ ). Conventional aerobic sewage sludge stabilization process can be modified using aerobic thermophilic stabilization (Antolin et al., 2010, Cheng et al., 2015, Cheng et al., 2015, Layden et al., 2007, De la Rubia et al., 2013. The aim of the aerobic sewage sludge stabilization process is to obtain a biologically stable sewage sludge, reduce the amount of putrefactive and bacteria and preliminary hygienisation of the sewage sludge. Other advantages include: reducing the amount of organic compounds and dry matter and enriching the sewage sludge with humic substances, which improves its fertilizing properties. On the other hand, aerobic stabilization is regarded as an energy-consuming method due to the continuous supply of oxygen. Another disadvantage of aerobic stabilization is that a biogas production does not take place in the process. In

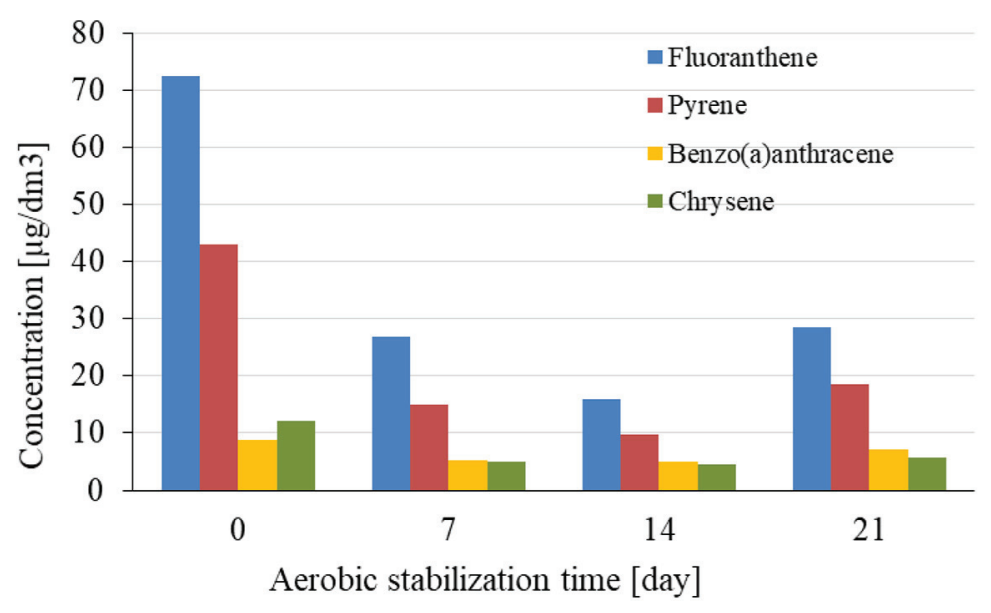

Fig. 5. Concentration of 4-ring PAHs during aerobic stabilization (reactor S12) 
the anaerobic processes carried out in closed fermentation chambers, biogas is generated, which is a source of additional benefits, such as heat and electricity (Li et al., 2019). This may be the reason that most of the research described in the literature focuses mainly on the investigations carrying under anaerobic conditions (Macherzyński et al., 2014). Boruszko investigated the sewage sludge coming from dairy sewage treatment plants using anaerobic sewage sludge stabilization process. He inoculated the sewage sludge with strains of effective microorganisms (EM). He noticed that in both with EM and without EM in the samples, a significant increase in the total PAHs content in the first phase of fermentation (acid fermentation) was observed after 7 days of the process. The decrease in total PAHs was observed after 14 days of fermentation compared to the value after one week of carrying the experiment (except post-flotation sewage sludge). In the following weeks, the concentration of 16 PAHs continued to decrease in all types of sewage sludge. However, in the samples without EM it was lower than in the sewage sludge with EM inoculation. The loss of the majority of hydrocarbons studied was noticed in the final phase of fermentation (Boruszko, 2017). Another study was carried out by co-authors on the determination of PAH changes in the sewage sludge and reject water samples during methane fermentation carried out under sulfates or nitrates reducing conditions. The concentration of 16 PAHs in sewage sludge was reduced by $30 \%$ on average and under nitrate-reducing conditions by $32 \%$ on average after 20 days of the fermentation process (Włodarczyk-Makuła, 2011). Other studies focused on optimizing the PAH removal from sewage sludge during anaerobic fermentation process. It was shown that the increase in temperature between $35^{\circ} \mathrm{C}$ and $55^{\circ} \mathrm{C}$ influenced the removal of the heaviest PAHs significantly. Finally, it was shown that the effectiveness of PAHs removal and methanogenic efficiency were closely related. The rate of biogas production can be used as an indicator of bacterial activity in the removal of PAHs (Trably et al., 2003). The changes of PAHs in the chemically stabilized municipal sewage sludge with the use of Fenton reagent or calcium oxide were also investigated (Wiśniowska, 2008). As already stated, the number of data describing the effectiveness of PAH removal from sewage sludge using the aeration process is limited, which suggests the necessity to continue the research.

\section{CONCLUSIONS}

The total concentration of naphthalene as well as 3- and 4-ring PAHs was significantly higher in the reject water coming from the industrial sewage sludge compared to municipal sewage sludge that indicates a significant load of industrial sewage sludge with hydrocarbons. The control of hydrocarbons content during aerobic stabilization process of sewage sludge showed fluctuations in concentration of reject water, but after the process they were lower than the initial ones. In the reject water originating from the municipal sewage sludge the decrease in concentration of sum of hydrocarbons grouped according to the number of rings in molecule was in the range of $11-65 \%$, whereas in the reject water originating from the mixture of municipal sewage sludge and industrial sewage sludge, it was in the range of $55-99 \%$. This confirms the presence of the microorganisms able to decompose PAHs in the sewage sludge coming from coking wastewater. The removal efficiency of 3-ring hydrocarbons under aerobic conditions was higher compared to 4-ring PAHs. In the further studies, it is planned to continue the research using various types of sludge (municipal and industrial) and it is also important to establish the proportions of sludge dose in order to optimize the efficiency of the aerobic stabilization of sewage sludge process.

\section{Acknowledgment}

The scientific research was funded by the statute subvention of Czestochowa University of Technology, Faculty of Infrastructure and Environment.

\section{REFERENCES}

1. Abbasian F., Lockington R., Mallavarapu M., Naidu R. 2015. A Comprehensive Review of Aliphatic Hydrocarbon Biodegradation by Bacteria. Applied Biochemistry and Biotechnology, 176, 670-699.

2. Abdel-Shafy HI., Mansour MSM. 2016. A review on polycyclic aromatic hydrocarbons: Source, environmental impact, effect on human health and remediation. Egyptian Journal of Petroleum, 25, 107-123.

3. Antolín MC., Muro I., Sánchez-Díaz M. 2010. Sewage sludge application can induce changes in antioxidant status of nodulated alfalfa plants. Ecotoxicology Environmental Safety, 73(3), 436-442.

4. Boruszko D. 2017. Research on the influence of anaerobic stabilization of various dairy sewage sludge on biodegradation of polycyclic aromatic 
hydrocarbons PAHs with the use of effective microorganisms. Environmental Research, 155, 344-352.

5. Cheng J., Dai Y., Zhang C., Dai J. 2015. Study of sludge stabilization for dual processes of thermophilic micro-aerobic and anaerobic digestion. Chinese Journal of Environmental Engineering, 9(12), 6059-6064.

6. Cheng J., Kong F., Zhu J., Wu X. 2015. Effects of stabilization and sludge properties in a combined process of anaerobic digestion and thermophilic aerobic digestion. Environmental Technology, 36(21), 2786-2795.

7. Council Directive 86/278/EEC of 12 June 1986 on the protection of the environment, and in particular of the soil, when sewage sludge is used in agriculture

8. Dat ND., Chang MB. 2017. Review on characteristics of PAHs in atmosphere, anthropogenic sources and control technologies. Science of the Total Environment, 60, 682-693

9. De la Rubia MA., Riau V., Raposo F., Borja R. 2013. Thermophilic anaerobic digestion of sewage sludge: focus on the influence of the start-up. A review. Critical Reviews in Biotechnology, 33(4), 448-460.

10. Fijałkowski K., Rorat A., Grobelak A., Kacprzak MJ. 2017. The presence of contaminations in sewage sludge - The current situation. Journal of Environmental Management, 203, 1126-1136.

11. Gupte A., Tripathi A., Rudakiya D., Gupte S. 2016. Bioremediation of Polycyclic Aromatic Hydrocarbon (PAHs): A Perspective. The Open Biotechnology Journal, 10, 363-378.

12. Haddaoui I., Mahjoub O., Mahjoub B., Boujelben A., DiBella G. 2016. Occurrence and distribution of PAHs, PCBs, and chlorinated pesticides in Tunisian soil irrigated with treated wastewater. Chemosphere, 146, 195-205.

13. Haritash AK., Kaushik CP.2009. Biodegradation aspects of polycyclic aromatic hydrocarbons (PAHs): a review. Journal of Hazardous Materials, 169, 1-15.

14. Kelessidis A. Stasinakis AS. 2012. Comparative study of the methods used for treatment and final disposal of sewage sludge in European countries. Waste Management, 2012,32 (6), 1186-1195.

15. Kozak J., Włodarczyk-Makuła M. 2018. Photo-oxidation of PAHs with calcium peroxide as a source of the hydroxyl radicals. E3S Web of Conferences, $30,1-8$.

16. Lawal AT. 2017. Polycyclic aromatic hydrocarbons. A review. Cogent Environmental Science, 3, 1-89.

17. Layden NM., Mavinic DS., Kelly HG., Moles R., Barlett J. 2007. Autothermal thermophilic aerobic digestion (ATAD) Part I: Review of origins, design, and process operation. Journal of Environmental Engineering, 6, 665-678.

18. Li Y., Chen Y., Wu J. 2019. Enhancement of methane production in anaerobic digestion process: A review. Applied Energy, 240, 120-137.
19. Liu C., Li K., Yu L., Xu Y., Huang B., Wu J., Wang Z. 2013. POPs and their ecological risk in sewage sludge of waste water treatment plants in Beijing, China. Stochastic Environmental Research and Risk Assessment volume, 27, 1575-1584.

20. Liu Y., Gao M., Zhang A., Liu Z. 2017. Strengthen effects of dominant strains on aerobic digestion and stabilization of the residual sludge, Bioresource Technology, 235, 202-210.

21. Macherzyñski B., Włodarczyk-Makuła M. 2018. Biochemical Neutralization of Coke Excess Sewage Sludge During Anaerobic Digestion Process. Chemical and Biochemical Engineering Quarterly, 32(2), 239-246.

22. Macherzyński B., Włodarczyk-Makuła M., Nowacka A.2014. Desorption of PAHs from solid phase into liquid phase during co-fermentation of municipal and coke sewage sludge Desalination and Water Treatment, 52(19-21), 3859-3870.

23. Petersen SO., Henriksen K., Mortensen GK., Krogh PH., Brandt KK., Sorensen J. 2003. Recycling of sewage sludge and household compost to arable land: fate and effects of organic contaminants, and impact on soil fertility. Soil \& Tillage Research, 72, 139-52.

24. Qu C., Albanese S., Lima A, Hope D., Pond P., Fortelli A, et al. 2019. The occurrence of OCPs, PCBs, and PAHs in the soil, air, and bulk deposition of the Naples metropolitan area, southern Italy: Implications for sources and environmental processes. Environment International, 124, 89-97.

25. Rubio-Clemente A., Torres-Palma RA., Penuela GA. 2014. Removal of polycyclic aromatic hydrocarbons in aqueous environment by chemical treatments: a review. Science of the Total Environment. 478, 201-225.

26. Statistical yearbook of the Republic of Poland 2018. Warszawa: GUS; 2020.

27. Włodarczyk-Makuła M., Popenda A. 2015. Quantitative changes of PAHs in water and wastewater during treatment processes. In: Wastewater Treatment: Occurrence and Fate of Polycyclic Aromatic Hydrocarbons, 47-70.

28. Włodarczyk-Makuła M. 2011. Behaviour of PAHs during sewage sludge fermentation in the presence of sulphate and nitrate. Desalination and Water Treatment, 33, 178-184.

29. Zennegg M.,Munoz M., Schmid P., Gereckea A.C. 2013. Temporal trends of persistent organic pollutants in digested sewage sludge (1993-2012). Environment International, 60, 202-208.

30. Trably E., Patureau D., Delgenes JP. 2003. Enhancement of polycyclic aromatic hydrocarbons removal during anaerobic treatment of urban sludge. Water Science \& Technology, 48, 53-60.

31. Wiśniowska E. 2008. Effect of chemical stabilisation of sewage sludge on the fate of PAHs. Archives of Environmental Protection, 34, 249-257. 